\title{
Limno-terrestrial Tardigrada of the Nearctic Realm
}

\author{
Harry A. MEYER* and Juliana G. HINTON \\ Department of Biological and Environmental Sciences, McNeese State University, Lake Charles, Louisiana, U.S.A. 70609 \\ *e-mail corresponding author: hmeyer@mcneese.edu
}

\begin{abstract}
We examined all available records of limno-terrestrial tardigrade distribution in the Nearctic realm (Greenland, Canada, Alaska, the continental United States of America, and northern Mexico), both to compare this fauna with other realms and to investigate distribution within North America. We included only those records in which tardigrades had been identified to species. Of 204 Nearctic limno-terrestrial tardigrade species, 38 were cosmopolitan, while 55 were unique to the Nearctic realm. The Nearctic tardigrade fauna is most similar to the Palearctic, with 135 species in common, 39 of which have not been reported elsewhere. The Nearctic realm shares 82 species with the Neotropical realm, only 10 which are not also Palearctic. These data are consistent with the geological history of the three realms, and indicate a distinction between Laurasian and Gondwanan tardigrade faunas. Although little is known about limno-terrestrial tardigrade distribution in much of North America, there are several excellent regional or local surveys. Many species are distributed widely throughout the continent, but 30.0\% of Nearctic species have been reported from a single site. Cluster analysis of the fauna of 11 Nearctic regions shows that the Arctic and sub-Arctic fauna constitute a regional fauna distinct from the rest of the continent. Ecological analysis is hampered by inconsistent reporting of tardigrade substrate, though available data suggest little substrate specificity in terrestrial tardigrades. Most species are found in both mosses and lichens. Many are also present in soil and leaf litter, but few are found only in these substrates.
\end{abstract}

Key words: tardigrades, limno-terrestrial, North America, Nearctic, biogeography, substrate specificity

\section{INTRODUCTION}

The Nearctic biogeographical realm consists of Greenland, Canada, Alaska, the continental United States of America, and the northern tier of Mexican states. Knowledge of the distribution of terrestrial and freshwater tardigrades (Phylum Tardigrada) in this realm is patchy at best. Although some areas have been sampled intensively, most are poorly known. Even though the first reports of Nearctic tardigrades were in the Nineteenth Century (Bailey 1850; Beal 1880; Packard 1873), serious study of the distribution of this phylum in North America only began after 1900. Richters (1908) and Murray (1910) published the first Canadian surveys. Mathews (1938) reported 32 species from North America, including 12 in the United States. The first record of the phylum in Nearctic Mexico (May 1948) reported a single species, supplemented thereafter by only two studies (Schuster 1971; Hoffman \& Jiménez 1994). Petersen (1951) conducted the first rigorous survey of Greenland Tardigrada.

Although most studies of Nearctic limno-terrestrial tardigrades (i.e., those inhabiting freshwater, cryptogams, soil, and leaf litter) have had a narrow geographical focus, concentrating on the diversity and ecology of a single site or at most a relatively small area, they nevertheless provide some distribution data (Curtin 1948, 1957; May 1948; Ramazzotti 1956, 1957; Higgins 1959, 1960; Baumann 1960; Gustavson 1963; Grigarick et al. 1964, 1973, 1983; Schuster \& Grigarick 1966, 1970, 1971; Boudrye 1967; Crowe \& Higgins 1967; Beasley
1968, 1972, 1990, 2001; Kimmel \& Meglitsch 1969; Mehlen 1969; Sayre 1969; Landreth \& Thomas 1970; Węglarska 1970; Barrett \& Kimmel 1972; Iharos 1973; Fleeger \& Hummon 1975; Nelson 1975; Schuster 1975; Bernard 1977; Pilato 1977; Schuster et al. 1977, 1980; Christenberry 1979; Christenberry \& Higgins 1979; Christenberry \& Mason 1979; Crowe et al. 1979; Wainberg \& Hummon 1981; Węglarska \& Kuc 1980; Dastych 1982, 1987; Kristensen 1982; Lee \& Woolever 1983; Dewel et al. 1985; Meininger et al. 1985; Beasley \& Pilato 1987; Dewel \& Dewel 1987; Kathman \& Nelson 1987, 1989; Maucci 1987; Nelson et al. 1987; Pilato \& Beasley 1987, 2005; Meininger \& Spatt 1988; Maucci 1988, 1991; Manicardi 1989; Séméria \& Elin 1989; Kathman 1990b, c; Séméria 1990; Nelson 1991; Tarter et al. 1992; van Rompu et al. 1992; Nelson \& McGlothlin 1993, 1996; Tarter \& Nelson 1993, 1994; Strayer et al. 1994; Kendall-Fite \& Nelson 1996; Guidetti 1998; Grøngaard et al. 1999; Peters \& Dumjahn 1999; Guidetti et al. 2001; Hohl et al. 2001; Meyer 2001; Nelson \& Adkins 2001; Nichols et al. 2001; Romano et al. 2001; Pilato \& Binda 2003; Guidetti et al. 2006). However, some investigators have surveyed the tardigrade fauna of larger regions. These include southern Greenland (Maucci 1996), New Brunswick (Argue 1971, 1972, 1974), Newfoundland (Bateman \& Collins 2001), Labrador (Boeckner et al. 2006), Vancouver Island (Kathman 1990a; Kathman \& Dastych 1990), the Appalachians (Riggin 1962, 1964; Bartels \& Nelson 2006), Florida (Meyer 2006a), Oklahoma (Beasley 1978), Missouri (Hidalgo \& Coombs 1985), 


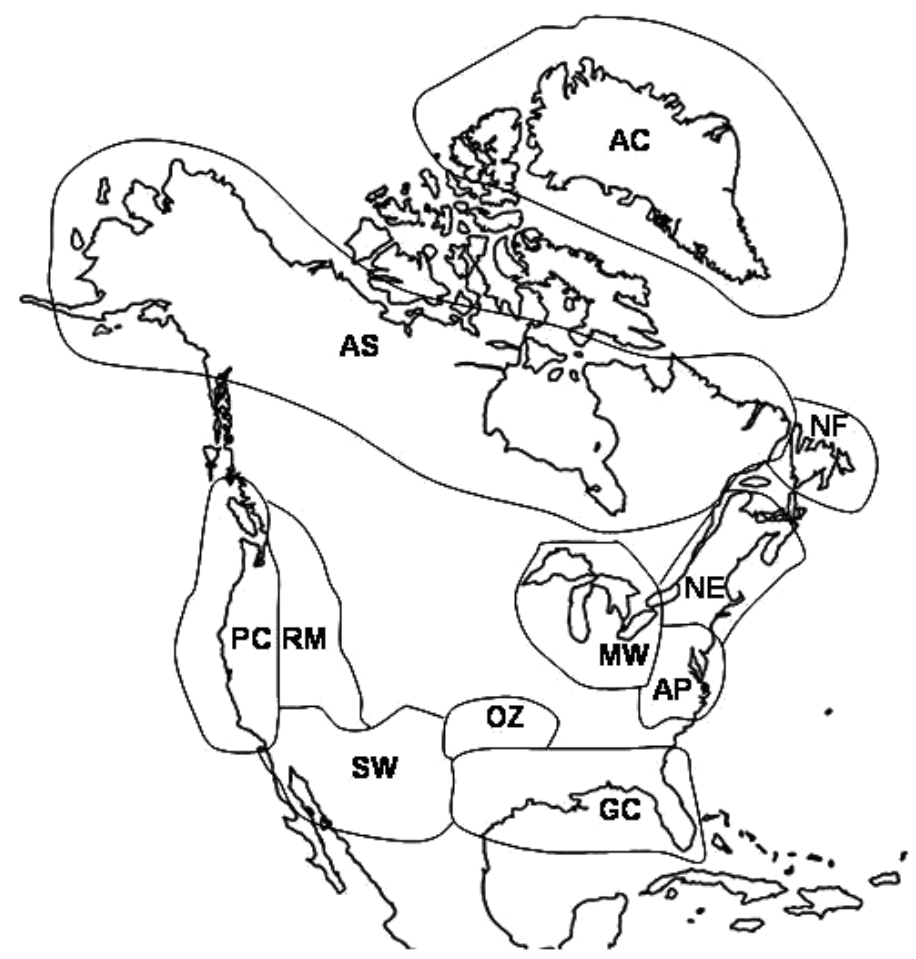

Fig. 1. Nearctic regions used for cluster analysis. $\mathrm{AC}=$ Arctic Cluster, $\mathrm{AS}=$ mainland Arctic and sub-Arctic, $\mathrm{NF}=\mathrm{Newfoundland}$, $\mathrm{NE}=$ New England and the Northeastern United States, MW = Midwestern states and provinces, AP = Appalachians, OZ = Ozarks, $\mathrm{GC}=$ Gulf Coast and Georgia, $\mathrm{RM}=$ Rocky Mountains, $\mathrm{PC}=$ Vancouver Island and the Pacific Coastal States of the U.S.A., and SW $=$ Southwestern U.S.A. and northern Mexican states.

Illinois (Puglia 1964), New Mexico (Beasley 1988), the American Pacific coast states (Schuster \& Grigarick 1965), and Sonora (Schuster 1971).

A cluster analysis of global limno-terrestrial tardigrade taxa showed that the Nearctic and Palearctic fauna were more highly associated than were Nearctic and Neotropical species (McInnes \& Pugh 1998). Pugh \& McInnes (1998) performed the only analysis of biogeographical associations within the Arctic. They found that the tardigrades of Greenland and Axel Heiberg Island formed a coherent "Arctic cluster" with those of Iceland and Svalbard.

Few studies have investigated substrate specificity in terrestrial Nearctic tardigrades. Kimmel \& Meglitsch (1969) and Meyer (2006a) found little evidence for substrate specificity beyond a preference is some species for lichens or mosses.

In this paper we present the results of a survey of the literature on Nearctic limno-terrestrial Tardigrada. We compare the Nearctic fauna to those of the Palearctic and Neotropical realms, and analyze the Nearctic fauna for regional associations and evidence for terrestrial substrate specificity.

\section{METHODS}

We consulted 100 published papers, 2 dissertations, and 7 theses. From each we derived whatever data could be culled concerning distribution and substrate. We assigned species to U.S.A. counties (where possible), Canadian provinces and territories, Mexican states and to Greenland. Papers varied widely in the detail with which locations were reported. While some provided detailed records for each sample taken, many indicated only the county or state. Three U.S.A. species Echiniscus perarmatus Murray 1907, Macrobiotus higginsi Maucci 1987 and Hexapodibius christenberryae Pilato \& Binda 2003 - could not be assigned to states but only to larger regions. We also included unpublished data from our own collections of tardigrades in Louisiana and Vermont. We included only tardigrades that had been identified in the literature to a described species, i.e., we excluded collected tardigrades identified as "sp." and "cf." We accepted authors' identifications at face value, unless modified in a subsequent publication. All species identifications were harmonized with the taxonomy in Guidetti \& Bertolani (2005).

We compared the Nearctic tardigrade fauna with those of the Palearctic and Neotropical regions, as listed in McInnes (1994) and subsequent literature, by tallying the species in common. We divided the Nearctic realm into 11 regions (Fig. 1): the Nearctic portion of Pugh \& McInnes (1998)'s Arctic cluster (AC; 82 species), mainland Arctic and sub-Arctic sites (AS; 64 species), the island of Newfoundland (NF; 22 species), New Brunswick and the northeastern U.S. (NE; 32 species), southern Ontario and Midwestern states surrounding the 


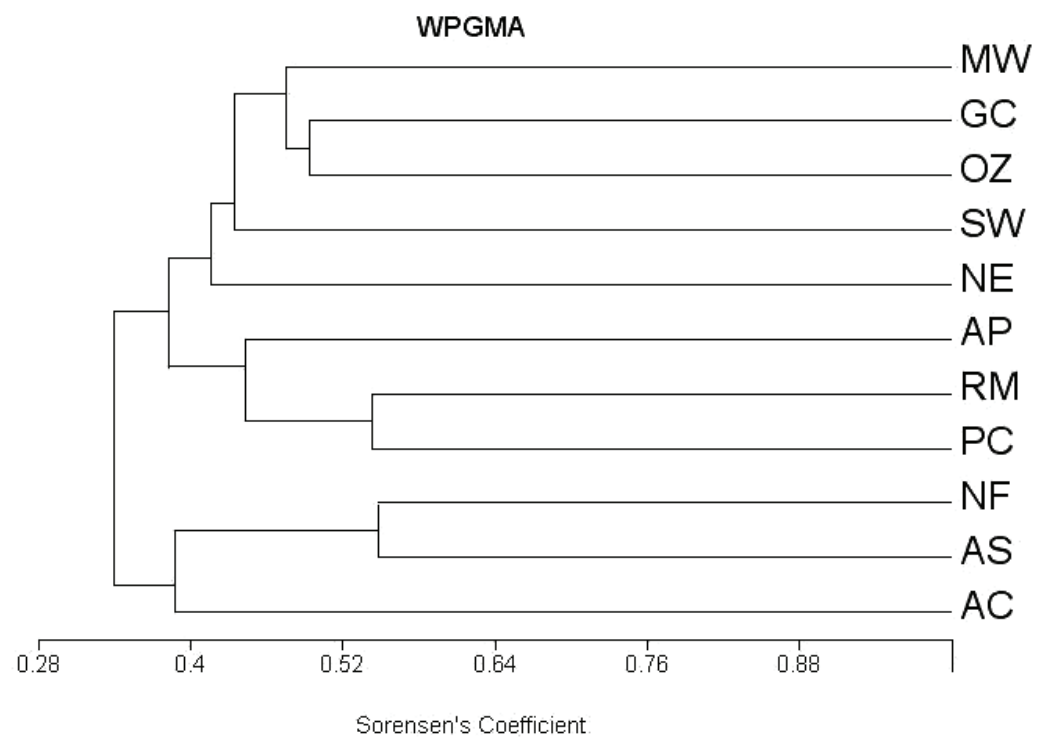

Fig. 2. WPMGA cluster analysis of Sorensen coefficients for the Nearctic tardigrade fauna. AC $=$ Arctic Cluster, AS = mainland Arctic and sub-Arctic, NF $=$ Newfoundland, $\mathrm{NE}=$ New England and the Northeastern United States, MW $=$ Midwestern states and provinces, $\mathrm{AP}=$ Appalachians, $\mathrm{OZ}=$ Ozarks, $\mathrm{GC}=$ Gulf Coast and Georgia, $\mathrm{RM}=$ Rocky Mountains, $\mathrm{PC}=$ Vancouver Island and the Pacific Coastal States of the U.S.A., and SW = Southwestern U.S.A. and northern Mexican states.

Great Lakes (MW; 31 species), the Appalachians and adjoining mountainous areas (AP; 84 species), the Ozarks and adjoining areas (OZ; 32 species), Georgia and the states of the Gulf Coast from Florida to eastern Texas (GC; 49 species), the Rocky Mountains and adjoining mountainous areas (RM; 61 species), Vancouver Island and the Pacific coastal states of the U.S.A. (PC; 68 species), and the southwestern U.S.A. and northern Mexican states (SW; 31 species). Although based on North American landforms, the number and boundaries of the regions are perforce to some extent arbitrary. We used cluster analysis to determine whether the Nearctic fauna demonstrated distinct regional groupings, employing a simple weighted pair-group mean analysis (WPGMA; MVSP 3.1 software) of a Sorensen species present/not present algorithm (Sneath \& Sokal 1973). The Sorensen coefficient can range from 0 to 1, with 0 indicating two regions have identical lists of species and 1 indicating complete difference.

All limno-terrestrial species were included in our biogeographical and distribution analyses. However, we excluded freshwater species from our analysis of substrate specificity. For terrestrial substrates, the quality of substrate information provided varied widely among papers. Some identify substrates to species, while others use larger categories, e.g., "moss," "lichen," "mosses and lichens," or "cryptogam." Some papers include no substrate data. Species were included for substrate analysis only if the substrate was reported at three or more separate sites. Papers do not always clearly distinguish between soil and leaf litter samples; therefore these were combined into one category, soil/leaf litter. We examined substrate specificity at two levels: pres- ence in cryptogams vs presence in soil/leaf litter (94 species), and presence in moss vs presence in lichens (73 species). We tallied the number of species in each category. Due to the wide variation in sampling methods and reporting of substrates in the literature, these data were not subjected to statistical analysis, but rather were examined for evidence of general trends.

\section{RESULTS}

In lichens from Essex County, Vermont, we have found three species previously unrecorded in the state: Milnesium tardigradum Doyère 1840, Macrobiotus tonollii Ramazzotti 1956, and Minibiotus furcatus (Ehrenberg 1859).

Currently 204 limno-terrestrial tardigrade species have been reported in the Nearctic realm. Of these, 18 have been found exclusively or primarily in freshwater habitats; the remainder are terrestrial. Thirty-six species are cosmopolitan sensu Pilato \& Binda (2001), i.e., present in at least five biogeographical realms. Although many Nearctic tardigrade species are widespread, 61 species have been reported from only a single site. The number of species per sample ranges from 1 to 8 , and per site from 1 to 13 .

The Nearctic tardigrade fauna includes 55 species unrecorded in other biogeographical realms. The realm shares 135 of its species with the Palearctic, including 63 exclusive to those two realms. It shares 82 species with the Neotropical realm, but only 10 of those are not also present in the Palearctic.

The Nearctic regions form two well-defined clusters (Fig. 2): the Arctic and sub-Arctic NF, AS, and AS (Sorensen coefficients $0.387-0.548$ ) and the remaining 8 
regions (0.383-0.543). Within the former, NF and AS are highly associated (0.548). South of Arctic and subArctic North America, the most closely associated regions are RM and PC (0.543) and $\mathrm{OZ}$ and GC (0.494).

Terrestrial tardigrades have been reported from lichens, mosses, liverworts, club mosses, anthophytes, fungi, bark, soil, and leaf litter. About one-third of Nearctic tardigrade species have been found in both cryptogams and soil/leaf litter samples; few are found exclusively in the latter (Tab. 1). Although most cryptogam-inhabiting species have been found in both mosses and lichens, a substantial number have only been found in the former (Tab. 1). Few are restricted to lichens.

Tab. 1. Substrate specificity in Nearctic terrestrial tardigrades. The only species included are those for which the substrate was recorded at 3 or more separate sites.

\begin{tabular}{lc}
\hline Substrate category & n. species \\
\hline Cryptogams only & 64 \\
Both cryptogams and soil/leaf litter & 27 \\
Soil/leaf litter only & 3 \\
Both moss and lichen & 50 \\
Moss only & 18 \\
Lichen only & 5 \\
\hline
\end{tabular}

\section{DISCUSSION}

Large areas of the Nearctic realm have seen little or no sampling. Even in better-studied areas, the high level of small-scale spatial variability in tardigrade distribution (Meyer 2006b) makes it likely that species have been missed. Better estimates of Nearctic tardigrade species richness can be obtained by a wider application of the sampling methodology and species accumulation curves employed in All Taxa Biological Inventories (e.g., Bartels \& Nelson 2006). Accurately assessing regional variation would be facilitated if consistent standards of specific diagnosis were used (see Pilato \& Binda 2001; Guidetti \& Bertolani 2005). Many papers consulted in this survey were published before the development of such rigorous standards. For example, the "hufelandi group" was once considered one (or a few) cosmopolitan Macrobiotus species, but systematic revision (Biserov 1990a, b; Bertolani \& Rebecchi 1993) has shown that it includes a large number of non-cosmopolitan species.

The number of reported tardigrade species in the Nearctic realm is roughly equivalent to the known species richness of the Neotropics (Pilato et al. 2004), but less than half the number recorded in the Palearctic (Pilato \& Binda 2001). It was noted that a relatively high percentage $(68.4 \%)$ of limno-terrestrial tardigrade species were limited to a single biogeographic region (Pilato \& Binda 2001), with only $30.0 \%$ of Nearctic species endemic to North America. Pilato \& Binda (2001) characterized 53 species, $6.8 \%$ of the global fauna, as cosmopolitan. Of these species 36 have been found in the Nearctic realm, constituting $17.6 \%$ of the continent's known species richness, a much higher percentage than the global proportion. No doubt much of the difference between New World and Palearctic species richness and level of endemism reflects historical differences in sampling intensity.

Nearctic Tardigrada have much more in common with the Palearctic than the Neotropical fauna. This pattern reflects the breakup of Pangaea into Laurasia and Gondwana 135 million years ago (McInnes \& Pugh 1998). The tardigrade fauna of North America shares few non-cosmopolitan species with the Afrotropical, Australasian, Antarctic or Indomalaysian realms.

Pugh \& McInnes (1998) noted that the Arctic cluster had a close affinity with the North American and northern Eurasian clusters. Our cluster analysis, conducted at a continental level, shows that Arctic and sub-Arctic North America have a regional tardigrade fauna associated with, but distinct from the rest of the Nearctic realm (Fig. 2). Indeed, 37.6\% of the Arctic and sub-Arctic species have not been found elsewhere in North America.

The most highly-associated Nearctic regions are all geographically contiguous: NF-AS, RM-PC, and GCOZ (Figs 1 and 2). The only high association we found between non-contiguous regions was between AP and RM-PC. Whether this high association between widelyseparated areas has a biogeographical explanation, or simply results from the fact that these areas are the most heavily sampled non-Arctic regions, cannot be ascertained at this time.

Most Nearctic tardigrade species are either widelydistributed throughout the continent or have highly-restricted known distributions. Evidence for distinctive regional faunas - suites of species widely-distributed within regions of the continent but absent elsewhere outside the Arctic is limited. We have identified 5 species widespread in the southeastern United States that are not found elsewhere, and there are several possible candidates in the western United States. However, until the distribution of North American tardigrades is much better known the existence of such regional faunas must remain speculation.

Investigators of North American tardigrades have collected mosses and lichens far more often than any other terrestrial substrate. Table 1 supports the contention that most tardigrade species are equally at home in both moss and lichen (Meyer 2006a). Indeed, many of the 23 species reported in only one of the two substrates are from areas where only one substrate was collected (e.g., Boeckner et al. 2006 collected only mosses in Labrador). Although many Nearctic tardigrade species are found in both cryptogams and soil/leaf litter, very few widespread species have been reported only from soil and leaf litter. Given the paucity of sampling in Nearctic soil and leaf litter, the possibility that a larger number of species are specific to those substrates cannot be precluded. 


\section{ACKNOWLEDGMENTS}

We wish to thank the Inter-Library staff at McNeese State University for their untiring assistance and Mark A. Paulissen for a helpful critique of the manuscript.

\section{REFERENCES}

Argue, C.W. 1971. Some terrestrial tardigrades from New Brunswick, Canada. Can. J. Zool., 49: 401-415.

Argue, C.W. 1972. Tardigrades from New Brunswick, Canada. 2. Can. J. Zool., 50: 87-94.

Argue, C.W. 1974. Tardigrades from New Brunswick, Canada. 3. Can. J. Zool., 82: 919-922.

Bailey, J.W. 1850. Microscopic observations made in South Carolina, Georgia, and Florida. Smithsonian Contrib. Knowledge, 2: 1-48.

Barrett, G.W. \& R.G. Kimmel. 1972. Effects of DDT on the density and diversity of tardigrades. Proc. Iowa Acad. Sci., 78: 41-42.

Bartels, P.J. \& D.R. Nelson. 2006. A large-scale, multihabitat inventory of the Phylum Tardigrada in the Great Smoky Mountains National Park, USA: a preliminary report. Hydrobiologia, 558: 111-118.

Bateman, L. \& M. Collins. 2001. A preliminary account of the tardigrades of Newfoundland. Zool. Anz., 240: 223-232.

Baumann, H. 1960. Beitrag zur Kenntnis der Tardigraden in Nord-Amerika. Zool. Anz., 165: 123-128.

Beal, F.E.L. 1880. Tardigrades and eggs. Am. Nat., 14: 593-594.

Beasley, C.W. 1968. Tardigrades from Kansas. Trans. Kans. Acad. Sci., 70: 464-470.

Beasley, C.W. 1972. Some tardigrades from Mexico. Southwest. Nat., 17: 21-29.

Beasley, C.W. 1978. The tardigrades of Oklahoma. Am. Midl. Nat., 99: 128-141.

Beasley, C.W. 1988. Altitudinal distribution of Tardigrada of New Mexico with the description of a new species. Am. Midl. Nat., 120: 436-440.

Beasley, C.W. 1990. Tardigrada from Gunnison Co., Colorado, with the description of a new species of Diphascon. Southwest. Nat., 35: 302-305.

Beasley, C.W. 2001. Photokinesis of Macrobiotus hufelandi (Tardigrada, Eutardigrada). Zool. Anz., 240: 233-236.

Beasley, C.W. \& G. Pilato. 1987. Two new species of Doryphoribius (Eutardigrada, Hypsibiidae) from North America. Animalia, 14: 99-105.

Bernard, E.C. 1977. A new species of Hexapodibius from North America, with a redescription of Diphascon belgicae (Tardigrada). Trans. Am. Microsc. Soc., 96: 476-482.

Bertolani, R. \& L. Rebecchi. 1993. A revision of the Macrobiotus hufelandi group (Tardigrada, Macrobiotidae) with some observations on the taxonomic characters of eutardigrades. Zool. Scripta, 22: 127-152.

Biserov, V.I. 1990a. On the revision of the genus Macrobiotus. The subgenus Macrobiotus s. str.: a new systematic status of the hufelandi group (Tardigrada, Macrobiotidae). Communication 1. Zool. Zh., 69: 5-17. (in Russian)

Biserov, V.I. 1990b. On the revision of the genus Macrobiotus. The subgenus Macrobiotus s. str.: a new systematic status of the hufelandi group (Tardigrada, Macrobiotidae). Communication 2.1. Zool. Zh., 69: 38-50. (in Russian)

Boeckner, M., M. Collins, J. Finney-Crawley \& L. Bateman. 2006. The bryofauna of remote coastal Labrador: including a review of current Canadian records. Zootaxa, 1105: 1-16.

Boudrye, M.R. 1967. Notes on the Tardigrada of Minnesota. Proc. Minnesota Acad. Sci., 26: 195-199.

Christenberry, D. 1979. On the distribution of Echiniscus kofordi and E. cavagnaroi (Tardigrada). Trans. Am. Microsc. Soc., 98: 469-471.
Christenberry, D. \& R.P. Higgins. 1979. A new species of Pseudodiphascon (Tardigrada) from Alabama. Trans. Am. Microsc. Soc., 98: 508-514.

Christenberry, D. \& W.H. Mason. 1979. Redescription of Echiniscus virginicus with notes on life history, range, and geographic variation. J. Ala. Acad. Sci., 50: 47-61.

Crowe, J.H. \& R.P. Higgins. 1967. The revival of Macrobiotus areolatus Murray (Tardigrada) from the cryptobiotic state. Trans. Am. Microsc. Soc., 86: 286-294.

Crowe, J.H., I.M. Newell \& W.W. Thomson. 1979. Echiniscus viridis (Tardigrada): Fine structure of the cuticle. Trans. Am. Microsc. Soc., 89: 316-325.

Curtin, C.B. 1948. The tardigrade fauna of the District of Columbia. J. Wash. Acad. Sci., 38: 251-254.

Curtin, C.B. 1957. Studies on the tardigrades. II. Some tardigrades from Maryland. Pa. Acad. Sci. Publ., 31: 142-146.

Dastych, H. 1982. An annotated list of Alaskan Tardigrada. Pol. Polar Res., 3: 95-102.

Dastych, H. 1987. Two new species of Tardigrada from the Canadian Subarctic with some notes on sexual dimorphism in the family Echiniscidae. Entomol. Mitt. Zool. Mus. Hamb., 8: 319-333.

Dewel W.C. \& R.A. Dewel. 1987. Study of a moss community containing Milnesium tardigradum parasitizied by a chytridiomycetous fungus. In: R. Bertolani (Ed.), Biology of Tardigrades. Selected Symposia and Monographs U.Z.I., 1. Mucchi Editore, Modena, Italy: 45-46.

Dewel R.A., J.D. Joines \& J.J. Bond. 1985. A new chytridiomycete parasitizing the tardigrade Milnesium tardigradum. Can. J. Bot., 63: 1525-1534.

Fleeger, J.W. \& W.D. Hummon. 1975. Distribution and abundance of soil Tardigrada in cultivated and uncultivated plots of an old field pasture. Mem. Ist. ital. Idrobiol., 32 Suppl.: 93-112.

Grigarick, A.A., F. Mihelčič \& R.O. Schuster. 1964. New Tardigrada from western North America: I, Pseudechiniscus. Proc. Biol. Soc. Wash., 77: 5-8.

Grigarick, A.A., R.O. Schuster \& D. Nelson. 1983. Heterotardigrada of Venezuela (Tardigrada). Pan-Pac. Entomol., 59: 64-77.

Grigarick, A.A., R.O. Schuster \& E.C. Toftner. 1973. Macrobiotus montanus from California (Tardigrada: Macrobiotidae). Pan-Pac. Entomol., 49: 229-231.

Grøngaard, A., P.J.A. Pugh \& S.J. McInnes. 1999. Tardigrades, and other cryoconite biota, on the Greenland ice sheet. Zool. Anz., 238: 211-214.

Guidetti, R. 1998. Two new species of Macrobiotidae (Tardigrada: Eutardigrada) from the United States of America, and some taxonomic considerations of the genus Murrayon. Proc. Biol. Soc. Wash., 111: 663-673.

Guidetti, R., T. Altiero \& J.G. Hansen. 2006. A new species of freshwater tardigrades from Disko Island (Greenland) increases an unsolved paradox in tardigrade systematics. Hydrobiologia, 558: 69-79.

Guidetti, R. \& R. Bertolani. 2005. Tardigrade taxonomy: an updated check list of the taxa and a list of characters for their identification. Zootaxa, 845: 1-46.

Guidetti, R., R. Bertolani \& D. Nelson. 2001. Ecological and faunistic studies on tardigrades in leaf litter of beech forests. Zool. Anz., 238: 215-223.

Gustavson, T.C. 1963. A report on collecting, preparing, and mounting tardigrades from central eastern North Dakota. Proc. N. D. Acad. Sci., 17: 28-31.

Hidalgo, H. \& D. Coombs. 1985. Tardigrada from Missouri. Trans. Kans. Acad. Sci., 88: 121-134.

Higgins, R.P. 1959. Life history of Macrobiotus islandicus Richters with notes on other tardigrades from Colorado. Trans. Am. Microsc. Soc., 78: 137-157.

Higgins, R.P. 1960. Some tardigrades from the Piedmont of North Carolina. J. Elisha Mitchell Sci. Soc., 76: 29-35. 
Hoffmann, A. \& M.L. Jiménez. 1994. Tardígrados en México. An. Inst. Biol. Univ. Nac. Auton. Mex. Ser. Zool., 65: $297-$ 301.

Hohl, A.M., W.R. Miller \& D.R. Nelson. 2001. The distribution of tardigrades upwind and downwind of a Missouri coal-burning power plant. Zool. Anz., 240: 395-401.

Iharos, G. 1973. Angaben zur geographischen Verbreitung der Tardigraden. Opusc. Zool. Budapest, 12: 73-86.

Kathman, R.D. 1990a. Eutardigrada from Vancouver Island, British Columbia, Canada, including a description of Platicrista cheleusis n. sp. Can. J. Zool., 68: 1880-1895.

Kathman, R. D. 1990b. Isohypsibius woodsae, a new species of Eutardigrada (Tardigrada) from British Columbia. Can. Field-Nat., 104: 293-294.

Kathman, R.D. 1990c. Some tardigrades from Colorado, with a description of a new species of Macrobiotus (Macrobiotidae: Eutardigrada). Proc. Biol. Soc. Wash., 103: 300303.

Kathman, R.D. \& H. Dastych. 1990. Some Echiniscidae (Tardigrada: Heterotardigrada) from Vancouver Island, British Columbia, Canada. Can. J. Zool., 68: 699-706.

Kathman, R.D. \& D.R. Nelson. 1987. Population trends in the aquatic tardigrade Pseudobiotus augusti (Murray). In: R. Bertolani (Ed.), Biology of Tardigrades. Selected Symposia and Monographs U.Z.I., 1. Mucchi Editore, Modena, Italy: 158-168

Kathman, R.D. \& D.R. Nelson. 1989. Pseudodiphascon arrowsmithi, a new species of tardigrade from British Columbia, Canada (Macrobiotidae: Eutardigrada: Tardigrada). Entomol. Soc. Brit. Columbia, 86: 66-70.

Kendall-Fite, K. \& D.R. Nelson. 1996. Two new species of tardigrades from Short Mountain, Tennessee, U.S.A. Zool. J. Linn. Soc., 116: 205-214.

Kimmel, R.G. \& P.A. Meglitsch. 1969. Notes on Iowa tardigrades. Proc. Iowa Acad. Sci., 76: 454-462.

Kristensen, R.M 1982. New aberrant tardigrades from homothermic springs on Disko Island, West Greenland. In: D.R. Nelson (Ed.), Proceedings of the Third International Symposium on the Tardigrada. East Tennessee State University Press, Johnson City, Tennessee: 203-220.

Landreth, Jr., K. \& B. Thomas. 1970. Studies of the egg laying process in Tardigrada (Hypsibius [Isohypsibius] augusti) in Weld County. J. Colo.-Wyo. Acad. Sci., 7: 9.

Lee, L. \& P. Woolever. 1983. Occurrence of tardigrades in Adair County, Oklahoma. Proc. Okla. Acad. Sci., 63: 102.

Manicardi, G.C. 1989. Two new species of soil moss eutardigrades (Tardigrada) from Canada. Can. J. Zool., 67: 22822285 .

Mathews, G.B. 1938. Tardigrada from North America. Am. Midl. Nat., 19: 619-627.

Maucci, 1987. A contribution to the knowledge of the North American Tardigrada with emphasis on the fauna of Yellowstone National Park (Wyoming). In: R. Bertolani (Ed.), Biology of Tardigrades. Selected Symposia and Monographs U.Z.I., 1. Mucchi Editore, Modena, Italy: 187-210.

Maucci, W. 1988 (1991). Tre nuove specie di eutardigradi della Groenlandia meridionale. Boll. Mus. Civ. St. Nat. Verona, 15: 279-289.

Maucci, W. 1996. Tardigrada of the Arctic tundra with descriptions of two new species. Zool. J. Linn. Soc., 116: 185-204.

May, R.M. 1948. Noveau genre et espèce de tardigrade du Mexique: Haplomacrobiotus hermosillensis. Bull. Soc. Zool. France, 73: 95-97.

McInnes, S.J. 1994. Biogeographic distribution of terrestrial/freshwater tardigrades from current literature. J. Nat. Hist., 28: 257-352.

McInnes, S.J. \& P.J.A. Pugh. 1998. Biogeography of limnoterrestrial Tardigrada, with particular reference to the Antarctic fauna. J. Biogeogr., 25: 31-36.
Mehlen, R.H. 1969. New Tardigrada from Texas. Am. Midl. Nat., 81: 395-404.

Meininger, C.A. \& P.D. Spatt. 1988. Variations in tardigrade assemblages in dust-impacted Arctic mosses. Arctic Alpine Res., 20: 23-30.

Meininger, C.A., G.W. Uetz \& J.A. Snider. 1985. Variation in epiphytic microcommunities (tardigrade-lichen-bryophyte assemblages) of the Cincinnati, Ohio area. Urban Ecology, 9:45-61

Meyer, H.A. 2001. Tardigrades of Louisiana and Arkansas, United States of America. Zool. Anz., 540: 471-474.

Meyer, H.A. 2006a. Interspecific association and substrate specificity in tardigrades from Florida, Southeastern United States. Hydrobiologia, 558: 129-132.

Meyer, H.A. 2006b. Small-scale spatial distribution variability in terrestrial tardigrade populations. Hydrobiologia, 558: 133-139.

Murray, J. 1910. Tardigrada. Report on Scientific Investigations of the British Antarctic Expedition 1907-1909, 1: 81185.

Nelson, D.R. 1975. Ecological distribution of tardigrades on Roan Mountain, Tennessee-North Carolina. Mem. Ist. ital. Idriobiol., 32 Suppl.: 225-276.

Nelson, D.R. 1991. A new species of Diphascon from New Brunswick, Canada (Tardigrada). Can. J. Zool., 69: 19111915.

Nelson, D.R. \& R.G. Adkins. 2001. Distribution of tardigrades within a moss cushion: Do tardigrades migrate in response to changing moisture conditions? Zool. Anz., 240: 493500 .

Nelson, D.R., C.J. Kincer \& T.C. Williams. 1987. Effects of habitat disturbances on aquatic tardigrade populations. In: R. Bertolani (Ed.), Biology of Tardigrades. Selected Symposia and Monographs U.Z.I., 1. Mucchi Editore, Modena, Italy: 141-153.

Nelson D.R. \& K.L. McGlothlin. 1993. A new species of Hypsibius (Phylum Tardigrada) from Roan Mountain, Tennessee, U.S.A. Trans. Am. Microsc. Soc., 112: 140144.

Nelson, D.R. \& K.L. McGlothlin. 1996. A new species of Calohypsibius (Phylum Tardigrada, Eutardigrada) from Roan Mountain, Tennessee-North Carolina, U.S.A. Zool. J. Linn. Soc., 116:167-164.

Nichols, P.B., F.A. Romano III \& D.R. Nelson. 2001. Seasonal and altitudinal variation in the distribution and abundance of Tardigrada on Dugger Mountain, Alabama. Zool. Anz., 240: 501-504.

Packard, A.S. 1873. Discovery of a tardigrade. Am. Nat., 7: $740-841$

Peters, T. \& P. Dumjahn. 1999. Ecological aspects of tardigrade distribution on Disko Island, West Greenland. Ber. Polarforsch., 330: 64-75.

Petersen, B. 1951. The Tardigrade-Fauna of Greenland. Medd. Grønland København, 150: 1-94.

Pilato, G. 1977. Macrobiotus willardi, a new species of Tardigrada from Canada. Can. J. Zool., 55: 628-630.

Pilato, G. \& C.W. Beasley. 1987. Haplohexapodibius seductor n. gen. n. sp. (Eutardigrada Calohypsibiidae) with remarks on the systematic position of the genus. Animalia, 14: 65-71.

Pilato, G. \& C.W. Beasley. 2005. Haplomacrobiotus utahensis new species of Calohypsibiidae (Eutardigrada) from North America. Zootaxa, 879: 1-7.

Pilato, G. \& M.G. Binda. 2001. Biogeography and limno-terrestrial tardigrades: Are they truly incompatible binomials? Zool. Anz., 240: 511-516.

Pilato, G. \& M.G. Binda. 2003. Hexapodibius christenberryae, a new species of tardigrade from North America (Eutardigrada, Calohypsibiidae). Zootaxa, 130: 1-6.

Pilato, G., M.G. Binda, A. Napolitano \& E. Moncada. 2004. Remarks on some species of tardigrades of South America 
with the description of two new species. J. Nat. Hist., 38: 1081-1086.

Pugh, P.J.A. \& S.J. McInnes. 1998. The origin of Arctic terrestrial and freshwater tardigrades. Polar Biol., 19: 177182.

Puglia, C.H. 1964. Some tardigrades from Illinois. Trans. Am. Microsc. Soc., 83: 300-311.

Ramazzotti, G. 1956. Tre nuove specie di tardigradi ed altre specie poco comuni. Atti Soc. Ital. Sci. Nat. Mus. Civ. Stor. Nat. Milano, 95: 284-291.

Ramazzotti, G. 1957. Due nuove specie di tardigradi extraeuropei. Atti Soc. Ital. Sci. Nat. Mus. Civ. Stor. Nat. Milano, 96: 188-191.

Richters, F. 1908. Beitrag zur Kenntnis der Moosfauna Australiens und der Inseln der Pacifischen Oceans. Zool. Jahrb. Abt. Syst. Oekol. Geogr. Tiere, 26: 196-213.

Riggin, Jr., G.T. 1962. The Tardigrada of southwest Virginia: with the addition of a description of a new marine species from Florida. Virginia Agric. Exp. Stn, Tech. Bull., 152: 1145.

Riggin, Jr., G.T. 1964. Tardigrades from the southern Appalachian Mountains. Trans. Am. Microsc. Soc., 83: 277-282.

Romano, III, F.A., B. Barreras-Borrero \& D.R. Nelson. 2001. Ecological distribution and community analysis of Tardigrada from Choccolocco Creek, Alabama. Zool. Anz., 240: 535-541.

Sayre, R.M. 1969. A method for culturing a predaceous tardigrade on the nematode Panagrellus redivivus. Trans. Am. Microsc. Soc., 88: 266-274.

Schuster, R.O. 1971. Tardigrada from the Barranca del Cobre, Sinaloa and Chihuahua, Mexico. Proc. Biol. Soc. Wash., 84: 213-224.

Schuster, R.O. 1975. A new species of Parechiniscus from Utah (Tardigrada: Echiniscidae). Mem. Ist. ital. Idrobiol., 32 Suppl.: 333-336.

Schuster, R.O. \& A.A. Grigarick. 1965. Tardigrada from western North America with emphasis on the fauna of California. Univ. Cal. Publ. Zool., 76: 1-67.

Schuster, R.O. \& A.A. Grigarick. 1966. New Tardigrada from western North America: II, Echiniscus. Proc. Biol. Soc. Wash., 79: 127-130.

Schuster, R.O. \& A.A. Grigarick. 1970. Tardigrada of Santa Cruz Island, California. Pan-Pac. Entomol., 46: 184-193.

Schuster, R.O. \& A.A. Grigarick. 1971. Two new species of Echiniscus from the Pacific Northwest. Proc. Entomol. Soc. Wash., 73: 105-110.
Schuster, R.O., A.A. Grigarick \& E.C. Toftner. 1980. A new species of Echiniscus from California (Tardigrada: Echiniscidae). Pan-Pac. Entomol., 56: 265-267.

Schuster, R.O., E.C. Toftner \& A.A. Grigarick. 1977. Tardigrada of Pope Beach, Lake Tahoe, California. Wasmann J. Biol., 35: 115-136.

Séméria, Y. 1990. Les tardigrades de la côte orientale du Groenland. Résultats de la 3e expedition du G.E.C.R.P. au Scoresbysund. Bull. Mens. Soc. Linn. Lyon, 59: 325-332.

Séméria, Y. 2003. Tardigrades des cryoconites du Groenland. Exploration de l'inlandis et de ses abords immédiats. Bull. Mens. Soc. Linn. Lyon, 73: 191-192.

Séméria, Y. \& D. Elin. 1989. Les tardigrades du Groenland. Résultats de la 2e expedition du G.E.C.R.P. au Scoresbysund (côte orientale - 1985). Bull. mens. Soc. linn. Lyon, 58: 124-134.

Sneath, P.H.A. \& R.R. Sokal. 1973. Numerical Taxonomy. W.H. Freeman \& Co., San Francisco: 573 pp.

Strayer, D., D.R. Nelson \& E.B. O'Donnell. 1994. Tardigrades from shallow groundwaters in southeastern New York, with the first record of Thulinia from North America. Trans. Am. Microsc. Soc., 113: 325-332.

Tarter, D. \& D. Nelson. 1993. First records of tardigrades (Phylum: Tardigrada) from mosses in the Cranberry Glades Botanical Area in the Monongahela National Forest, Pocahontas County, West Virginia. Proc. W. Va. Acad. Sci., 65: 36.

Tarter, D. \& D. Nelson. 1994. Preliminary list of tardigrades (Phylum: Tardigrada) from mosses and liverworts in the Mononghela National Forest. Proc. W. Va. Acad. Sci., 66: 34.

Tarter, D., K. Ruggles, S. Gillenwater \& D. Nelson. 1992. First records of water bears (Phylum: Tardigrada) from West Virginia. Proc. W. Va. Acad. Sci., 1989, 61: 96-99.

Van Rompu, E.A., W.H. De Smet \& L. Beyens. 1992. Contributions to the Tardigrada of the Canadian HighArctic 1. Freshwater tardigrades from Devon Island, Northwest Territories. Can. Field-Nat., 106: 303-310.

Wainberg, R.H. \& W.D. Hummon. 1981. Morphological variation of the tardigrade Isohypsibius saltursus. Trans. Am. Microsc. Soc., 100: 21-33.

Węglarska, B. 1970. Hypsibius (Isohypsibius) smreczynskii spec. nov., a new species of freshwater tardigrade. Zesz. Nauk. Uniw. Jagiellonsk., Pr. Zool., 16: 107-114.

Węglarska, B. \& M. Kuc. 1980. Heterotardigrada from Axel Heiberg Island. Zesz. Nauk. Uniw. Jagiellonsk., Pr. Zool., 26: 53-66. 